\title{
Bud flush phenology and nursery carryover effect of paper birch provenances
}

\author{
Amalesh Dhar ${ }^{(1-2)}$, Nicole Balliet ${ }^{(1)}$, Christopher DB Hawkins ${ }^{(1-3)}$, \\ Michael R Carlson ${ }^{(4)}$, Vicky G Berger ${ }^{(4)}$, Ronald Mahoney ${ }^{(5)}$
}

Paper birch (Betula papyrifera Marsh) is an ecologically valuable species with a broad geographic distribution across the North America. Its diversity, versatility and enduring nature make it an ideal candidate for a selective breeding program in this region. However, an understanding of the genecology of this species is fundamental to deploy it successfully. Ten paper birch provenances were collected from British Columbia (BC, Canada) and northern Idaho (USA) along elevational transects to determine whether observed bud flush phenology was due to genetics and /or environmental variation or their interaction. Seedlings were grown at three different nurseries: University of Idaho $\left(46^{\circ} 44^{\prime} \mathrm{N}\right)$, Landing $\left(50^{\circ} 17^{\prime} \mathrm{N}\right)$ and Little Forestry $\left(54^{\circ} 00^{\prime} \mathrm{N}\right)$ and planted in a randomized single tree interlocking block design in three common gardens at Sandpoint, ID $\left(48^{\circ} 13^{\prime} \mathrm{N}\right)$, Skimikin, BC $\left(50^{\circ} 45^{\prime} \mathrm{N}\right)$ and Red Rock, BC (53 $\left.45^{\prime} \mathrm{N}\right)$. Results indicate that variation in the timing of bud flush is a complex interaction among local genetic characteristics and environmental conditions of the growing site. Birch bud flush followed a general geographic trend where provenances at the southern common garden (Sandpoint) required less time (Day of Year, DoY) and fewer growing degree days (GDD) compared to central (Skimikin) and northern (Red Rock) common gardens. Although there were significant differences in the timing of bud flush among provenances along an elevational gradient, none of the regions showed the expected linear elevational cline, trends were inconsistent. Further, birch bud flush was significantly influenced by nursery displacement effects in the initial year of establishment but disappeared within three years. These results provide an opportunity to characterize bud flush phenology of paper birch and would be useful for improving operational paper birch seed transfer programs in BC.

Keywords: Betula papyrifera, Common Garden, Elevational Cline, Growing Degree Day (GDD), Day Of Year (DoY), Nursery Carry Over Effect, Provenance Trial, Seed-transfer

\section{Introduction \\ Paper birch (Betula papyrifera Marsh) is one of the most widely distributed birch species in North America. Recently, resear- chers have shown that the presence of birch in mixedwood stands plays a significant role in nutrient cycling, and in the disease and in- sect pest control for conifers species (Carl-}

son et al. 2000a, Benowicz et al. 2001, Simard et al. 2004, Hawkins et al. 2012a). Moreover, the presence of birch in young conifer plantations improves soil nutrient status and reduces the risk of root disease (Carlson et al. 2000b, Simard et al. 2001, Richards et al. 2010). All these beneficial characteristics help to promote birch as a $\square$ (1) Mixedwood Ecology and Management Program, University of Northern British Columbia, 3333 University Way, V2N 4Z9 Prince George, BC (Canada); (2) University of British Columbia, 3333 University Way, Kelowna, BC (Canada); (3) Yukon Research Centre, Yukon College, Whitehorse, YT (Canada); (4) Kalamalka Research Station, BC Ministry of Forests and Range, 3401 Reservoir Road, Vernon, BC (Canada); (5) Department of Forest Resources, University of Idaho, Moscow, ID (USA)

\section{@ Amalesh Dhar (amalesh.dhar@ubc.ca)}

Received: Jun 03, 2014 - Accepted: Mar 16, 2015

Citation: Dhar A, Balliet N, Hawkins CDB, Carlson MR, Berger VG, Mahoney R, 2015. Bud flush phenology and nursery carryover effect of paper birch provenances. iForest 8: 809-817 [online 2015-05-19] URL: http://www.sisef.it/iforest/contents/?id=ifor1367-008

Communicated by: Andrea Piotti new commercial reforestation species in British Columbia (BC - Carlson et al. 2000a, Hamann \& Wang 2006, Hawkins et al. 2012b, Hawkins \& Dhar 2013). However, knowledge concerning geographic variation or patterns of genetic variation within and among provenances is scarce (Carlson et al. 2000a, 2000b, Hawkins \& Dhar 2012, Dhar et al. 2014). Therefore, further study in relation to variability in birch's phenotypic traits is needed prior to establishing seed zones and seed transfer guidelines.

Transfer of a provenance to a new environment may predispose it to both positive and negative impacts on growth depending on transfer direction (Hänninen 2006, ViheräAarnio \& Velling 2008). Moreover, when tree species are transferred to a new environment they must regulate the timing of bud flush and flowering during the spring, as well as the timing of growth cessation and dormancy development during late summer and fall, in order to reduce the risk of frost damage (Häkkinen et al. 1998). In this regard, bud flush phenology is critical because it determines the beginning of the growing season and the probability of damage due to late spring frosts (Cannell \& Smith 1986). However, the annual rhythm of bud development in many forest trees species (such as birch, Douglas fir - Pseudotsuga menziesii Mirb.) are controlled by chilling temperature, duration of chilling (for birch temperatures $\leq 5^{\circ} \mathrm{C}$ for a few weeks) and accumulation of spring heat sums (Junttila \& Hänninen 2012, Park et al. 2014). In addition, these chilling characteristics do not just determine susceptibility to frost damage. Chilling also affects bud and leaf development (Park et al. 2014) and can vary from species to species (Murray et al. 1989) or differ within species by latitudinal origin (Hannerz et al. 2003). After meeting the chilling requirement, positive temperatures lead to bud development and the process may accelerate when temperature starts to increase (Kramer 1994). However, extended photoperiod may overcome the lack of chilling if trees are exposed to long days before meeting their chilling requirement irrespective of provenance origin (Dhar \& Hawkins 2013). Although air temperature appears to be the most significant environmental factor influencing the initiation of bud flush in Betula spp., photoperiod and soil temperature may also play important roles (Fraser 1956, Linkosalo \& Lechowicz 2006, Hawkins \& Dhar 2012).

Apart from the above mechanisms regulating spring bud flush, observations from common garden studies at different geographic locations suggest variability in spring bud phenology within species. Studies in northern Europe suggest northern provenances of B. pubescens Ehrh., B. nana L., B. pendula (Sulkinoja \& Valanne 1987, My- 


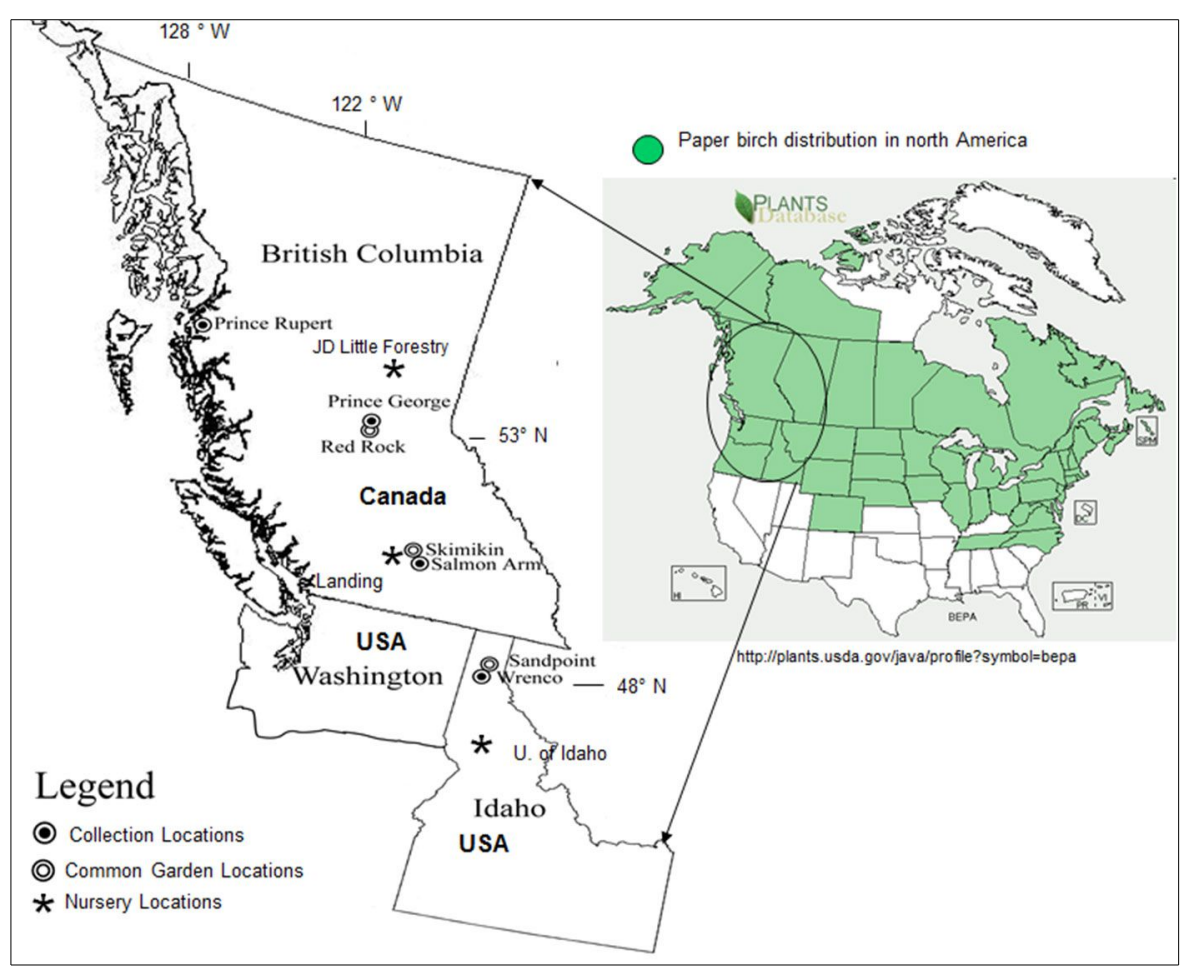

Fig. 1 - Paper birch provenance collection sites, common garden and nursery locations, and paper birch geographic distribution in North America.

king \& Heide 1995) and Acer platanoides L. (Westergaard \& Eriksen 1997) flush before southern provenances in a continental climate. Furthermore, continental provenances of $B$. pendula and B. pubescens flush earlier than those of coastal provenances (Myking 1997), while inland provenances of Ulmus glabra (Huds.) flushed earlier than those of coastal provenances (Myking \& Skroppa 2007). Conversely, other studies have demonstrated that southern provenances of $\mathrm{Pi}$ cea sitchensis (Bong.) Carr. and B. papyrifera flush slightly before northern provenances, and coastal populations of Pseudotsuga menziesii var. menziesii and B. papyrifera flush before continental provenances at a continental site (O'Driscoll 1976, Gould et al. 2011, Hawkins \& Dhar 2012. Therefore, it is important to determine the potential transfer responses before initiating any transfer guidelines.

A significant change in abiotic factors can occur in mountainous regions over a short distance (Vitasse et al. 2009). Therefore, elevational transects provide an ideal methodology for studying the variation of plant functional traits in response to environmental factors. Based on the study by Myking (1997), low elevation provenances of Betula spp. flush before high elevation provenances. A similar trend was also observed in provenance trials with other species, Fagus sylvatica L. in Polish and Finnish provenance trials (Chmura \& Rozkowski 2002, Westergaard \& Eriksen 1997). Conversely,
Sharik \& Barnes (1976) observed no elevational trend for flushing in a Betula spp. provenance trial in the USA. Therefore, an investigation of phenology responses along elevational transects is prerequisite before developing any seed transfer guidelines.

Nursery practices may lead to alteration of a population's phenotypic expression. This may ultimately influence the genetic acclimation (genotype by environment interaction - phenotype - in a single generation) of forest trees to plantation sites (Campbell \& Sorensen 1984). Consequently, any nursery with an environment greatly different from the site of seed origin may alter seedling growth and development after planting (Campbell \& Sorensen 1984, Hawkins 1998). Moreover, when northern provenances grown at southern nurseries are planted back in the north, their flushing phenology may be out of phase with that of the local populations because bud flush phenology depends not only on the present (growing) environment, but also on the environment in which the buds were formed (Westergaard \& Eriksen 1997, Heide 1993). Therefore, study of nursery carryover effects is another factor needed to consider before developing any seed transfer guidelines.

From a previous investigation on geographic variability of paper birch provenances ted some regional and population differentiation for certain traits. Despite promising results from this initial research, the populaacross BC, Hawkins \& Dhar (2012) sugges- tions of that study were not collected along elevational transects. Also, there was no investigation of nursery effects on birch bud flush. Therefore, a study was designed to investigate genecology (geographic variation in bud flush) of paper birch provenances at three different common garden locations in British Columbia (Canada) and Northern Idaho (USA) as well as to determine if there was any nursery carryover effect on birch bud flush. Campbell \& Sorensen (1984) and Hawkins (1998) suggested that a nursery environment/climate different from the stocks' site of origin could impact its field performance. In addition, our study also determined whether provenance responses were related to their site of origin (clinal variation).

\section{Materials and methods}

\section{Provenances}

In 1998, paper birch seed was collected from four different geographic regions: Salmon Arm, Prince George, Prince Rupert (British Columbia) and Idaho (Idaho, USA) (Fig. 1, Tab. 1). For Prince Rupert, Prince George and Salmon Arm regions, 5-8 provenance samples (depending on elevation range) were collected along elevational transects. Stands within each region were chosen within \pm 10 to $20 \mathrm{~m}$ of a pre-determined elevation, beginning at the bottom of an elevational transect and continuing every $100 \mathrm{~m}$ thereafter. Following initial analysis, 3 provenances from each of $3 \mathrm{BC}$ regions were selected (lowest, mid and highest elevation) for further experimentation. One population from northern Idaho was also sampled. At all sites, five non-clonal (half-sib or no genetic relationship as birch generally does not reproduce vegetatively in $\mathrm{BC}$ ) trees within each stand (provenance) were chosen for seed collection. These trees were of good health, form and had produced seed. Seed was collected and bulked to represent a provenance for each elevation.

\section{Nurseries and common gardens trial}

All 10 provenances of paper birch seedlings were grown at three different nurseries (NW: Canfor J.D. Little Forestry Centre, Prince George, BC; LN: Landing Nursery, Vernon, BC; UI: the University of Idaho, Moscow, ID - Tab. 1) to determine the importance of nursery practices and environment on the growth and acclimation of the seedlings after planting (Carlson et al. 2000a). Seeds were hand sown at each nursery in early May 1999 in PSB 515A styroblocks (Beaver Plastics, Edmonton, AB 284 seedlings $\mathrm{m}^{2}$ ), lifted in November 1999 and placed in cold storage until the spring of 2000 when they were planted. In spring 2000 , seedlings from all three nurseries were planted at 3 common gardens: late April in 
Tab. 1 - Geographic origin and climatic variables of different paper birch provenances, nurseries and common gardens. Mean annual temperature (MAT), mean temperature of the coldest month (MTCM), mean annual precipitation (MAP), extreme temperature difference (TD), and days of frost free period (FFP). Climate BC Model (http://climatemodels.forestry.ubc.ca/climatebc) based on 30-year mean climatic data, 1981-2009. (\#): Salmon Arm and Prince George sources are continental while Prince Rupert is a maritime climate. (*): All nursery locales and common garden sites have a continental climate.

\begin{tabular}{|c|c|c|c|c|c|c|c|c|c|}
\hline Region $^{\#}$ & Code & $\begin{array}{c}\text { Elevation } \\
\text { (m a.s.l.) }\end{array}$ & $\begin{array}{c}\text { Latitude } \\
(\mathrm{N})\end{array}$ & $\begin{array}{l}\text { Longitude } \\
\text { (W) }\end{array}$ & $\begin{array}{l}\text { MAT } \\
\left({ }^{\circ} \mathbf{C}\right)\end{array}$ & $\begin{array}{c}\text { MTCM } \\
\left({ }^{\circ} \mathrm{C}\right) \\
\end{array}$ & $\begin{array}{l}\text { MAP } \\
(\mathbf{m m})\end{array}$ & $\begin{array}{r}\text { TD } \\
\left({ }^{\circ} \mathrm{C}\right) \\
\end{array}$ & $\begin{array}{c}\text { FFP } \\
\text { (Day) }\end{array}$ \\
\hline Idaho & 13 & 870 & $48^{\circ} 13^{\prime}$ & $116^{\circ} 42^{\prime}$ & 6.8 & -2.6 & 958 & 20.8 & 134 \\
\hline Salmon Arm & 31 & 460 & $50^{\circ} 42^{\prime}$ & $119^{\circ} 25^{\prime}$ & 7.0 & -3.7 & 783 & 21.9 & 146 \\
\hline Salmon Arm & 33 & 760 & $50^{\circ} 42^{\prime}$ & $119^{\circ} 25^{\prime}$ & 5.8 & -4.5 & 783 & 21.4 & 132 \\
\hline Salmon Arm & 37 & 1200 & $50^{\circ} 42^{\prime}$ & $119^{\circ} 25^{\prime}$ & 4.0 & -5.7 & 783 & 20.7 & 111 \\
\hline Prince George & 51 & 700 & $53^{\circ} 55^{\prime}$ & $122^{\circ} 28^{\prime}$ & 4.3 & -6.1 & 618 & 21.1 & 104 \\
\hline Prince George & 54 & 1000 & $53^{\circ} 55^{\prime}$ & $122^{\circ} 28^{\prime}$ & 3.2 & -6.8 & 618 & 20.6 & 88 \\
\hline Prince George & 56 & 1200 & $53^{\circ} 55^{\prime}$ & $122^{\circ} 28^{\prime}$ & 2.4 & -7.3 & 618 & 20.3 & 78 \\
\hline Prince Rupert & 61 & 210 & $55^{\circ} 47^{\prime}$ & $128^{\circ} 45^{\prime}$ & 6.8 & -3.1 & 1472 & 19.2 & 168 \\
\hline Prince Rupert & 63 & 400 & $55^{\circ} 47^{\prime}$ & $128^{\circ} 45^{\prime}$ & 6.0 & -3.8 & 1472 & 19.3 & 156 \\
\hline Prince Rupert & 66 & 750 & $55^{\circ} 47^{\prime}$ & $128^{\circ} 45^{\prime}$ & 4.5 & -5.2 & 1472 & 19.4 & 132 \\
\hline \multicolumn{10}{|c|}{ Nursery location* } \\
\hline University of Ic & (UI) & 735 & $46^{\circ} 44^{\prime}$ & $116^{\circ} 58^{\prime}$ & 9.1 & 0.2 & 650 & 19.9 & 160 \\
\hline Landing (LN) & & 400 & $50^{\circ} 17^{\prime}$ & $119^{\circ} 16^{\prime}$ & 7.8 & -3.3 & 635 & 22.5 & 149 \\
\hline Little Forestry & er $(\mathrm{NW})$ & 650 & $54^{\circ} 00^{\prime}$ & $122^{\circ} 28^{\prime}$ & 3.9 & -8.6 & 679 & 24.3 & 106 \\
\hline \multicolumn{10}{|c|}{ Common garden location } \\
\hline Sandpoint (SP) & & 640 & $48^{\circ} 13^{\prime}$ & $116^{\circ} 40^{\prime}$ & 7.4 & -2.6 & 763 & 21.0 & 145 \\
\hline Skimikin (SK) & & 550 & $50^{\circ} 47^{\prime}$ & $119^{\circ} 24^{\prime}$ & 7.1 & -3.7 & 512 & 22.4 & 141 \\
\hline Red Rock (RR) & & 725 & $53^{\circ} 45^{\prime}$ & $122^{\circ} 43^{\prime}$ & 4.1 & -6.7 & 766 & 21.5 & 102 \\
\hline
\end{tabular}

Sandpoint (Idaho), early May in Skimikin (Salmon Arm) and mid-May in Red Rock (Prince George - Tab. 1). In this study we did not measure any nursery practice as each nursery had unique cultural regimes to optimize seedling growth with respect to local climatic conditions. As this was a preliminary study, it can be viewed as a benchmark for any follow-up studies.

All seedlings were identified according to provenance, geographic region and nursery for tracking their response in the common gardens. In total, 16 seedlings per provenance-nursery were planted at $2 \times 2 \mathrm{~m}$ spacing in a randomized single tree interlocking block design (16 trees per provenance planted as 4 trees in each of 4 replications for each of the 3 nurseries: $16 \times 3=48$ seedlings per provenance), allowing for comparisons among geographic region (4), provenance within geographic regions (10), nursery (3) and among common gardens (3). The experiment at different common garden locations was conducted under natural light (photoperiod), temperature and precipitation conditions. The average duration of photoperiod and temperature during the early growing season (April-June) varied by 20-90 minutes and up to $3{ }^{\circ} \mathrm{C}$ among the three common garden locations. Precipitation was similar at Sandpoint and Red Rock, while Skimikin was much drier (Tab. 1).

\section{Assessment of bud flush}

All ten provenances planted at Red Rock, Sandpoint and Skimikin were surveyed for spring bud flush in 2001 and 2003 (Tab. 1). The bud flush survey involved recording bud burst for 10 buds on a single branch, preferably the terminal. If the terminal did not have 10 buds, then buds on the next highest branch were examined and so on until a total of 10 buds were surveyed. For each survey, the total number of buds burst (for each tree) was recorded until all 10 buds flushed. The date of individual bud flush was identified when the first green ragged edges visually appear between the bud scales, almost like the opening of a "clam shell" (Hawkins \& Dhar 2012). All phenological assessments were done at least twice a week, and all trees were surveyed at all three common garden locations. In this study, $80 \%$ bud flush was chosen as the point of analysis, meaning the duration required to have 8 of 10 buds flush.

\section{Climate data}

All temperature data were acquired from the nearest weather reporting station (on site for Skimikin and Sandpoint, and within 10 $\mathrm{km}$ for Red Rock) to each common garden location. Red Rock is situated of the same glacial plain as the reporting station, therefore distance was not a concern for weather data. Temperature data were used to calculate growing degree days (GDD) or heat sum for each common garden location in each year. Budflush_GDD were calculated based on mean daily temperature starting on January $1^{\text {st }}$ of each year using the formula (eqn. 1):

$$
G D D=\sum\left[\frac{\left(T_{\max }+T_{\min }\right)}{2}-T_{\text {thres }}\right]
$$

(heat accumulated when $T>T_{\text {thres, }}$, and if $T<$ $T_{\text {thres }}$ then heat sum $=0$ ) where $T_{\max }$ is the maximum temperature and $T_{\min }$ the minimum temperature recorded over each $24-\mathrm{h}$ period, $T_{\text {thres }}$ is the threshold temperature. The threshold temperature for budflush GDD calculation was $0{ }^{\circ} \mathrm{C}$ (Heide 1993, Pellis et al. 2004, Rousi \& Pusenius 2005, Hawkins \& Dhar 2012). Day length was calculated on the $21^{\text {st }}$ day of each month for each population and common garden using the US Naval Observatory tables (http://www.weatherima ges.org/latlonsun.html). The different climatic variables were estimated for each provenance by using Climate $\mathrm{BC}$ version 4.72 , (Wang et al. 2012 - http://climatemodels.fo restry.ubc.ca/climatebc/).

\section{Data analysis}

All data were analyzed based on $80 \%$ bud flush using SYSTAT ${ }^{\circledR}$ (version 12, SYSTAT Software Inc) general linear model (GLM). During GLM, Type III sums of squares (Yates's weighted squares of means) was used as our data were unbalanced (number of provenance per region was not equal). In the literature there is ongoing debate about the use of sums of squares for unbalanced data. Some suggest using Type II sums of squares (Yates's weighted squares of means - Macnaughton 1998, Langsrud 2003), while other researchers suggest using Type III sums of squares (Lewsey et al. 1997, Shaw \& Mitchell-Olds 1993, Hector et al. 2010). We used Type III sums of squares for the GLM.

Initially, both provenance and region were considered as main effects for statistical analysis. When region was considered as a main effect, all provenances within a region were pooled to form an analytical unit and the analysis was run with four regions (Prince 
George, Prince Rupert, Salmon Arm and Idaho). However, GLM for both provenance and geographic region showed similar results for significance and $\mathrm{F}$ values. Therefore, a nested GLM was conducted, where different provenances are nested within region (independent variable). This was considered a main effect and modeled in the GLM procedure for $80 \%$ bud flush and growing degree days (budflush_GDD - dependent variable) to describe the geographic variation for paper birch provenances. The final model used in the analysis was as follows (eqn.2):

$$
\begin{aligned}
B_{80 \%}= & m+G+N+P(R)+ \\
& G \times N+G \times P(R)+N \times P(R)+\varepsilon
\end{aligned}
$$

where $B_{80 \%}$ is the bud flush proportion $(80 \%$, the number of days required to reach 8 of 10 buds flushed), $m$ is the grand mean, $G$ is the common garden location, $N$ is the nursery, $P(R)$ is the provenance $(P)$ nested within the separate model was run for each year (2001 and 2003) due to different sample sizes. In this study, seed source was the only random factor and all the others were fixed.

Subsequently pairwise comparisons were conducted using Tukey's multiple comparison tests to determine specific differences among provenances. The relationship betgeographic region $(R)$, and $\varepsilon$ is the error. A

ween bud flush performance of provenances and their source climate for a given individual test site was used to improve and validate bud flush response functions. Therefore, simple regression analyses were carried out to look at the response of provenances planted at different common gardens as function of the climate differences between provenance source locations and the respective common gardens. Variables were duration of frost free period (FFP), mean annual temperature (MAT), degree days (DD) and mean annual precipitation (MAP). A similar regression analysis was also done with response variables (Day of Year, DoY and budflush_GDD) to predict the effect of seed transfer distance. Seed transfer distance was calculated based on the latitudinal difference of the seed origin and common garden location (latitude of seed origin - latitude of common garden location). To simplify the analysis of relationships between climate variables of provenance source location and bud flush, we employed a principle component analysis (PCA). The PCA was conducted using the programming language $\mathrm{R}$ version 3.0.1 (R Core Team 2012). For all response variables, general normality tests were carried out with SYSTAT ${ }^{\circledR}$ version 12.0 and transformation was made when required.

Tab. 2 - Results of the GLM analysis for days (budflush DoY) to $80 \%$ spring bud flush and growing degree days (budflush_GDD) in 2001 and 2003. Significant results $(\alpha=0.05)$ are reported in italic.

\begin{tabular}{llrrrr}
\hline Variable & Factor & $\begin{array}{r}\text { Sum-of- } \\
\text { Squares }\end{array}$ & df & F-Ratio & $\boldsymbol{P}$ \\
\hline 2001: & Garden & 62795.43 & 2 & 1061.34 & $<0.001$ \\
Budflush_DoY & Nursery & 283.28 & 2 & 4.79 & 0.009 \\
n=755) & Provenance (Region) & 322.89 & 6 & 1.93 & 0.073 \\
& Garden $\times$ Nursery & 32.43 & 4 & 0.27 & 0.895 \\
& Garden $\times$ Provenance (Region) & 509.55 & 12 & 1.44 & 0.144 \\
& Nursery $\times$ Provenance (Region) & 288.43 & 12 & 0.81 & 0.638 \\
& Error & 21181.59 & 716 & - & - \\
\hline 2001: & Garden & 678785.94 & 2 & 456.04 & $<0.001$ \\
Budflush_GDD & Nursery & 26367.71 & 2 & 4.49 & 0.012 \\
$(\mathrm{n}=755)$ & Provenance (Region) & 29742.09 & 6 & 1.69 & 0.060 \\
& Garden $\times$ Nursery & 3542.93 & 4 & 0.30 & 0.877 \\
& Garden $\times$ Provenance (Region) & 52862.91 & 12 & 1.50 & 0.119 \\
& Nursery $\times$ Provenance (Region) & 25647.90 & 12 & 0.73 & 0.725 \\
& Error & 102921.44 & 716 & - & - \\
\hline 2003: & Garden & 80615.06 & 2 & 787.95 & $<0.001$ \\
Budflush_DoY & Nursery & 50.17 & 2 & 0.49 & 0.613 \\
$(\mathrm{n}=758)$ & Provenance (Region) & 1437.13 & 6 & 4.68 & $<0.001$ \\
& Garden $\times$ Nursery & 46.90 & 4 & 0.23 & 0.922 \\
& Garden $\times$ Provenance (Region) & 863.72 & 12 & 1.41 & 0.157 \\
& Nursery $\times$ Provenance (Region) & 484.55 & 12 & 0.79 & 0.662 \\
& Error & 36780.63 & 719 & - & - \\
\hline 2003: & Garden & 62164.03 & 2 & 8.04 & $<0.001$ \\
Budflush_GDD & Nursery & 4193.38 & 2 & 0.54 & 0.582 \\
$(\mathrm{n}=758)$ & Provenance (Region) & 125855.48 & 6 & 5.43 & $<0.001$ \\
& Garden $\times$ Nursery & 2414.51 & 4 & 0.16 & 0.960 \\
& Garden $\times$ Provenance (Region) & 63335.04 & 12 & 1.37 & 0.177 \\
& Nursery $\times$ Provenance (Region) & 28667.61 & 12 & 0.62 & 0.828 \\
& Error & 2779393.37 & 719 & - & - \\
\hline & & & & &
\end{tabular}

\section{Results}

Based on GLM analysis, of $80 \%$ bud flush among the common gardens was significantly different for budflush DoY and budflush GDD or heat sum requirement in both years (Tab. 2). Generally budflush_DoY and budflush GDD increased with increased common garden latitude (Fig. 2). Bud flush at the Sandpoint (southern) common garden was on an average 22 days in 2001 and 24 days in 2003 earlier than at the Red Rock (northern) common garden (Fig. 2a, Fig. 2c). When individual provenances were considered, provenance 33 from the Salmon Arm region required the least number of days for bud flush in both years at all three common garden locations, which was followed by the Idaho provenance (13). Considering heat requirement (budflush_GDD based on $0{ }^{\circ} \mathrm{C}$ ), different provenances responded differently at different common garden locations (Fig. 2 b, Fig. 2d). However in all instances, Prince Rupert provenances $(61,63$ and 66) required the greatest number of days (budflush_DoY) and amount of heat (budflush GDD) to flush. Tukey's test for multiple comparisons $(\alpha=0.05)$ showed a significant difference among geographic regions in all years, except for between Salmon Arm and Idaho in $2001(\mathrm{P}=0.084)$ and $2003(\mathrm{P}=0.792)$. This might be due to the close proximity and similar environmental conditions of the two geographic regions. When provenances were nested within geographic region, both budflush_DoY and budflush_GDD showed significant total population variation in 2003 and close to significant in 2001, indicating the existence of genetic differences among provenances and common garden locations' environmental impact (Tab. 2).

A significant difference among nurseries for birch bud flush was observed for both budflush_DoY and budflush_GDD at the beginning of seedling establishment (2001), but the relationship was not significant in 2003 (Tab. 2). Provenances grown at Landing Nursery required the greatest number of days (budflush_DoY) and budflush_GDD as compared to the other two nurseries in 2001, while in 2003 the difference was considerably less, thus also indicating the absence of a nursery carryover effect (Fig. 3a, Fig. 3b, Fig. 3c, Fig. 3d).

The influence of elevation on paper birch bud flush showed an inconsistent trend at all three common garden locations. There were significant differences $(\mathrm{P}<0.001)$ in the timing of bud flush (budflush_DoY) and budflush_GDD among provenances along an elevational transect for each of the Prince George, Prince Rupert and Salmon Arm regions at all three common garden locations, except Prince Rupert provenances at Red Rock (Fig. 4a, Fig. 4b). The influence of elevation showed an inconsistent trend and different regions required different bud- 

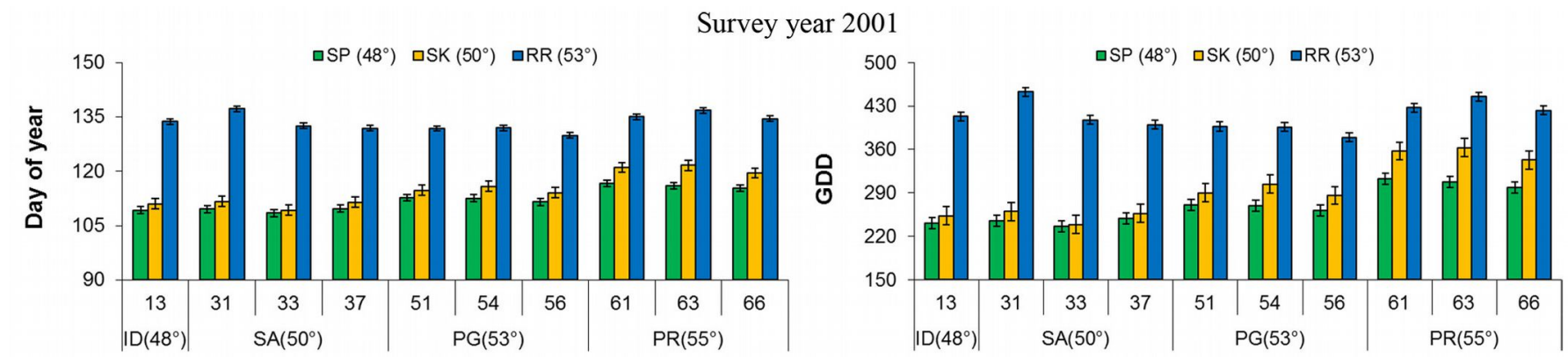

a)

Provenance and region[latitude]

b)

Survey year 2003
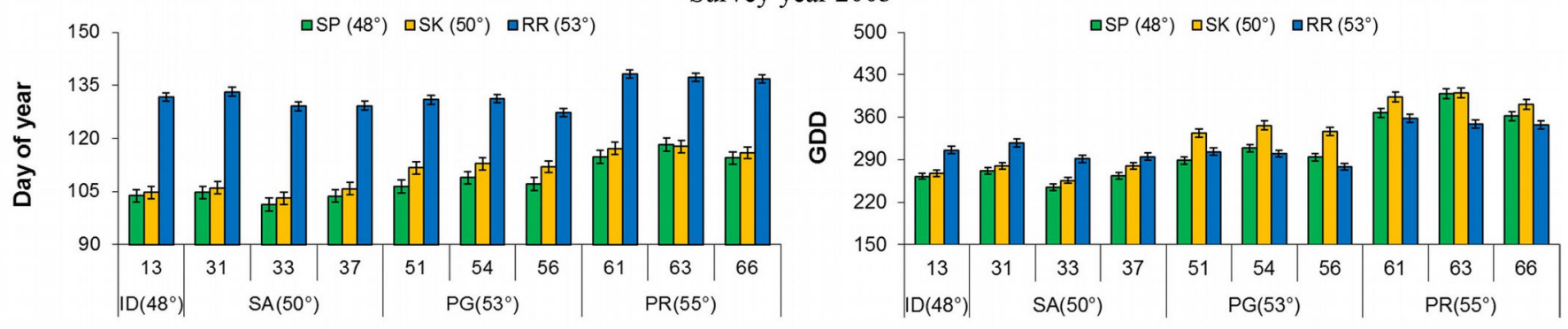

c)

Provenance and region [latitude]

d)

Provenance and region [latitude]

Fig. 2 - Least square mean (LSM) of budflush_DoY and budflush_GDD for 80\% bud flush ( \pm SE) by provenance, region and latitude at each common garden in 2001 and 2003. (GDD): Growing degree days; (SP): Sandpoint; (SK): Skimikin; (RR): Red Rock; (SA): Salmon Arm; (ID): Idaho; (PG): Prince George; (PR): Prince Rupert.

flush_DoY and budflush_GDD to flush. For flush_GDD for flush at all three common example, the middle elevation provenance garden locations than provenances from (760 m a.s.1.) from Salmon Arm region re- higher (1200 m a.s.1.) or lower (460 m a.s.1.) quired fewer budflush_DoY and less bud- elevation provenance $(1000 \mathrm{~m}$ a.s.1.) requiring more budflush_DoY (Fig. 4a) and budflush_GDD to flush (Fig. 4b).

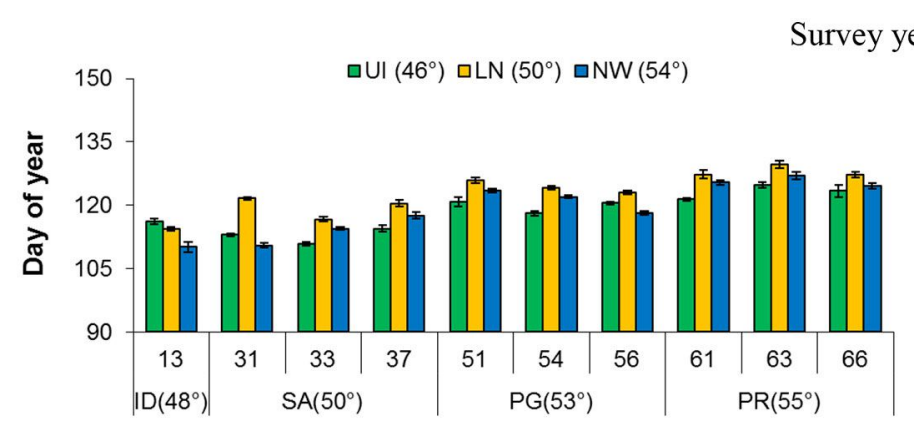

a)

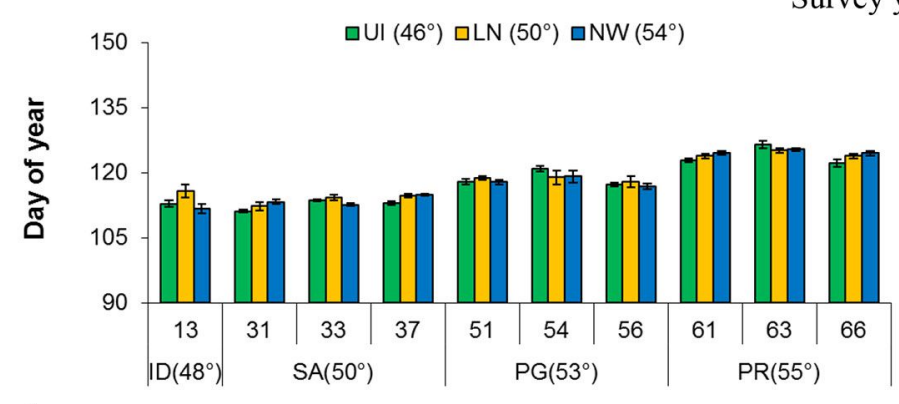

c)
Provenance and region [latitude]

Provenance and region [latitude]

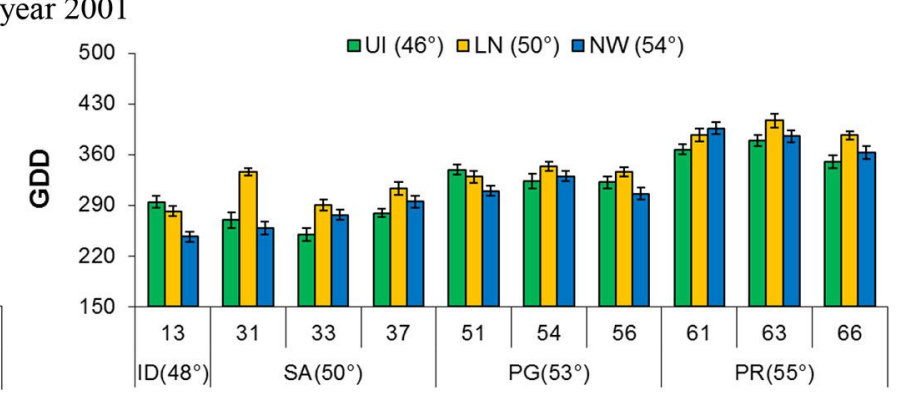

b)

Provenance and region [latitude]

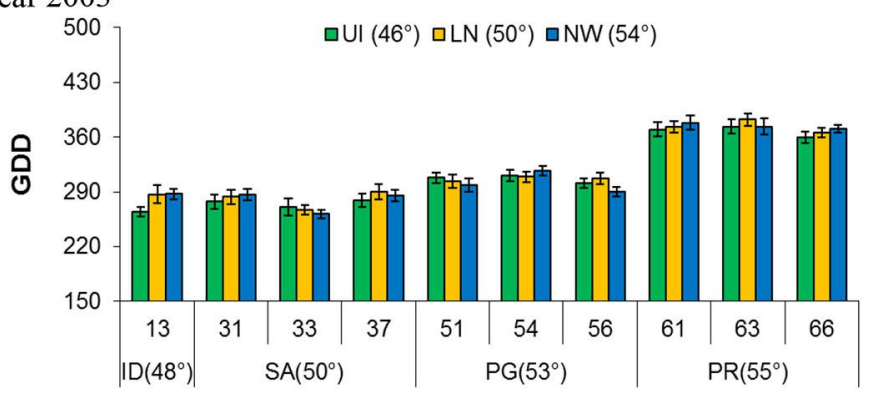

d)

Provenance and region [latitude]

Fig. 3 - Least square mean (LSM) of Budflush_DoY and budflush_GDD in 2001 and 2003 to $80 \%$ bud flush ( \pm SE) by provenance, region and latitude at each nursery with common garden pooled. (GDD): Growing degree days; (SP): Sandpoint; (SK): Skimikin; (RR): Red Rock; (SA): Salmon Arm; (ID): Idaho; (PG): Prince George; (PR): Prince Rupert. 


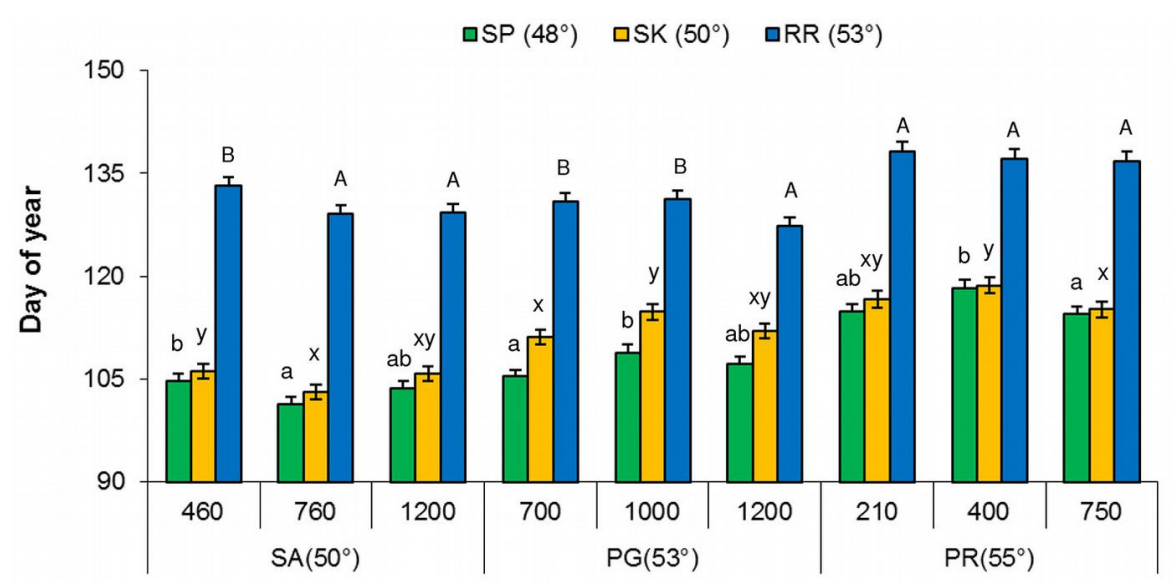

a)

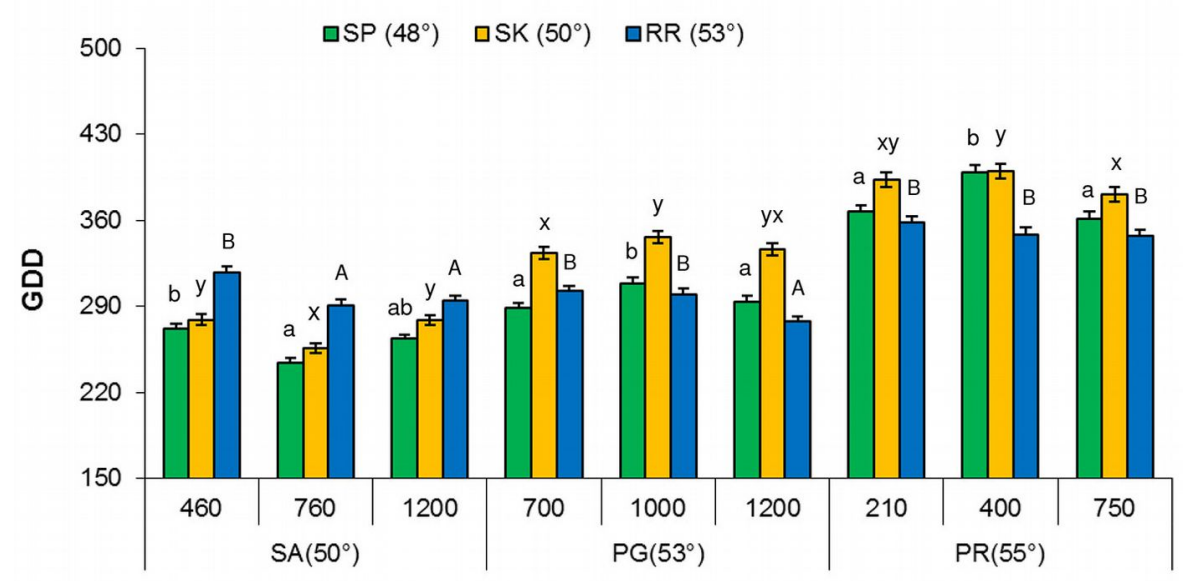

b)

Region and elevation

A linear relationship $(\mathrm{P}<0.001)$ was observed between the timing of bud flush (budflush_DoY) and latitudinal seed transfer distance (Fig. 5). The most rapid bud flush was observed with decreasing seed transfer distance towards the south at the southern common gardens, whereas at the northern com-

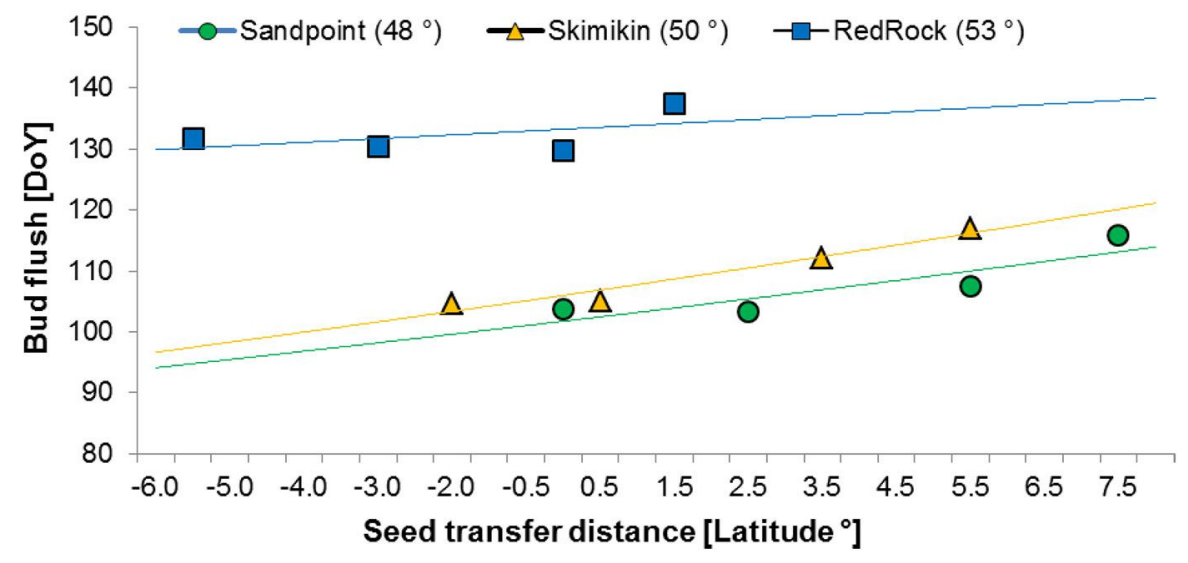

Fig. 5 - Day of the Year to $80 \%$ bud break by provenance in relation to latitudinal seed transfer distance for Red Rock (upper line), Skimikin (middle line) and Sandpoint (lower line) common gardens. (DoY): Day of year; (Seed transfer distance): latitude of seed origin latitude of garden location. mon garden the opposite trend was observed (Fig. 5). However without any apparent detrimental effect on phenology (e.g., buds fail to flush,, multiple dominant buds), provenances may be transferred up to $5^{\circ}$ of latitude toward the north and $7^{\circ}$ of latitude toward the south.
Fig. 4 - Least square mean (LSM) of Budflush DoY and budflush GDD for $80 \%$ bud flush ( \pm SE) by elevation at each common garden location along elevational transects for each climatic region in 2003. (SP): Sandpoint; (SK): Skimikin; (RR): Red Rock; birch bud flush values followed by the same letter $(\mathrm{a}, \mathrm{b}$, c or $\mathrm{A}, \mathrm{B}, \mathrm{C}$, or $\mathrm{x}, \mathrm{y}, \mathrm{z}$ ) within each region along elevational transect are not significantly different $(\alpha=0.05$, Tukey's test for multiple comparison with region along elevational transect, meter a.s.1.).
When regression analysis was carried out for budflush DoY, budflush_GDD and seed transfer distance for bud flush against provenance source location climatic variables (MAT, DD, FFP and MAP), there was no correlation or a very poor relationship (low $\mathrm{R}^{2}$ ) was observed. None of the source variables explained more than $25 \%$ of the observed variation (see Tab. SM1 - Supplementary Material). Therefore, further principal components analysis (PCA) was conducted to determine the impact of source location climate variables on bud flush (Tab. SM2 and Fig. SM1 - Supplementary Material). The PCA identified three main variation components, which in total explained $99.1 \%$ of the data set variability. Component I contributed $66.7 \%$ to the variance (eigenvalue $=2.7)$, component II contributed $32.2 \%$ (eigenvalue $=1.29$ ) and component III contributed $0.2 \%$ eigenvalue $=1.22$ ) . FPP, MAT and DD showed strong correlations with the component I, while MAP with the component II.

\section{Discussion}

Paper birch planted at Sandpoint (Idaho, USA) flushed slightly earlier than those 
planted at Skimikin (BC), and much earlier than those planted at Red Rock (BC - Fig. 2 ). This indicated that birch bud flush follows a general geographic trend and progresses from south to north (Kriebel \& Wang 1962, Hawkins \& Dhar 2012). A similar phenological trend was also observed in a genetic study on paper birch carried out by Morgenstern (1996). Apart from the geographic (common garden) location, it is evident that the observed bud flush is a consequence of local temperature or photoperiod or their interaction ( $\mathrm{Li}$ et al. 2003). When we consider the average temperature in January, February, March and April at the common garden location, Sandpoint $(-3.5,-0.9,+3.7$ $+7.4{ }^{\circ} \mathrm{C}$, respectively) was warmer than Skimikin $\left(-4.6,-1.2,+3.6,+6.7^{\circ} \mathrm{C}\right)$ and Red Rock $\left(-9.2,-5.9,-0.4,+4.6^{\circ} \mathrm{C}\right)$. This implies that temperature during the winter and spring played an important role in regulating the timing of birch bud flush, which is consistent with other studies (Heide 1993, Simpson et al. 2000, Linkosalo \& Lechowicz 2006, Pudas et al. 2008, Hawkins \& Dhar 2012). According to Heide (1993), warmer weather in January, February and March considerably reduced the thermal requirement for Betula spp. bud flush if the fall chilling requirement had been met. This sug gests that if a southward transfer is associated with warmer temperature then bud flush will be faster, while for a northward transfer, associated with cooler temperatures, bud flush should take longer.

Besides air temperature, photoperiod may also play an important regulatory role on birch bud flush because air temperature may vary significantly from year to year, while photoperiod does not (Häkkinen et al. 1998) Therefore, many temperate and boreal plant species rely on photoperiod to constrain their development to a "safe period" and the consequence of this photoperiodic constraint appears to increase with increasing latitude of seed origin (Morison \& Morecroft 2006). Although this was not a controlled photoperiod experiment, previous controlled photoperiod and translocation experiments in this region suggest that photoperiod had a significant impact on paper birch bud flush (Hawkins \& Dhar 2012). Therefore, we may assume that photoperiod itself or an interaction between local temperature and photoperiod could have an impact on birch flush. Li et al. (2003) observed that long photoperiod promoted bud flush at warmer temperatures. In addition, local soil temperature may be another contributory factor which could influence spring bud phenology of paper birch. The Red Rock common garden soil remains below zero in the early growing season compared to the Skimikin and Sandpoint common gardens. Birch with warm roots $\left(14^{\circ} \mathrm{C}\right.$ throughout the experimental period) flushed significantly earlier than those with cold roots (mean $0{ }^{\circ} \mathrm{C}$ ) in greenhouse and controlled growth chamber experiments (Hawkins \& Dhar 2012).

The nursery carryover effect on paper birch bud flush appears to be overcome within three years of initial seedling establishment. This implies that nursery effect may not be a significant residual factor in the timing of paper birch bud flush. In another study, the same group of provenances also showed a nursery carryover effect for height growth up to four years after planting (Dhar et al. 2014). A similar result was also reported by Carlson et al. (2000b) in other paper birch provenance trials in British Columbia. The reasons for a nursery carryover effect were not identified, but it may be due to temperature effects during seedling dormancy induction in the nursery. Southern nurseries are much warmer than northern ones during the fall period. The nursery carryover effect was present in the stock planted in all common garden location as bud flush phenology depends not only on the present (growing) environment, but also on the environment in which the buds were formed (Westergaard \& Eriksen 1997, Heide 1993). Based on the study by Westergaard \& Eriksen (1997), low temperatures during bud formation of Acer platanoides L. resulted in a more shallow dormancy level, while Heide (1993) indicated that high autumn temperatures delay spring bud flush in Betula species. BowdenGreen \& Rooke (1980) and Lang (1989) reported that a photoperiod at the nursery location shorter than the seed source photoperiod may have a direct impact on seedling size variation, as photoperiod can markedly alter the vegetative development of woody plants, particularly the timing of growth cessation.

In this study, a clear population differentiation was expected as the elevational differences of the highest and lowest collected provenances were large and might limit gene flow (Vitasse et al. 2009). Nonetheless, the results indicate an inconsistent trend and birch bud flush did not proceed from the lowest elevation to the highest as previously suggested by Myking (1997) and Sulkinoja \& Valanne (1987). This was unexpected, but not unprecedented, as Sharik \& Barnes (1976) found an absence of elevational differentiation among populations of two $\mathrm{Be}$ tula species from the Appalachian Mountains grown in a Michigan common garden. They concluded that factors other than temperature do regulate bud flush, likely the photoperiod or a photoperiod-temperature interaction (Morgenstern 1996). Further investigation with a greater number of provenances is required to validate whether this elevational trend on birch bud flush is stable.

When provenances from continental or inland regions (Prince George) were compared with those of a maritime or coastal region (Prince Rupert), the order of bud flush fol- lowed a longitudinal or inverse continentality trend, i.e., continental populations flushed earlier than maritime populations. A similar result was reported by Wielgolaski \& Inouye (2003) in a Pinus sylvestris L. provenance trial where continental provenances flushed before coastal provenances at a continental site. This might be due to a maritime climatic effect. According to Veen (1954), provenances from maritime origin respond more slowly than continental provenances when brought to a continental site, because maritime climates experience gradually increasing temperatures in spring with long periods of late frosts; whereas continental climates experience rapidly increasing temperatures with short periods of late frosts. As a result, coastal provenances are exposed to forcing temperatures much earlier (late winter/early spring) than continental provenances, thereby they are "prevented" from growing by a longer chilling requirement, while provenances from a continental climatic region require a minimum amount of heat because there is less chance of late spring frosts (Myking 1997). Seed transfer from a continental to a coastal climate may result in premature bud flush and frost damage as frost resistance during bud break in paper birch is low (Hannerz 1994).

The coefficient of determination for the linear regressions to $80 \%$ bud flush are very low in all combinations, which indicate that factors other than latitude must be involved in explaining the variation among the provenances. Differences in climatic adaptation among the birch population might exist as origin of some of the provenances locations had different climatic conditions compared to that of the common gardens (Viherä-Aarnio \& Velling 2008). The best correlation with climate variables was found at Skimikin garden, which is almost in the middle of the provenances source location. Looking at latitudinal seed transfer distance, our results suggest that latitudinal transfer northward up to $5^{\circ}$ and southward up to $7^{\circ}$ may be possible without any detrimental effect on bud flush, as this only leads to a later bud flush than that of local provenances. Similar observations were also reported by Hawkins \& Dhar (2012) in another birch provenance trial in BC. For the same provenances trial, Dhar et al. (2014) reported that a transfer of $5^{\circ}$ latitude in both directions had no negative impact on $B$. papyrifera height growth. Given the small number of provenances in the study, this information should be used with caution.

\section{Conclusion}

The overall results of this short term experiment suggests that: (1) there is no single factor that determines the onset of bud flush in paper birch in a common garden; rather it is a complex interaction among local genetic 
characteristics and environmental conditions at the growing site; (2) none of the regions showed the expected elevational cline for bud flush; rather, inconsistent trends were observed; (3) nursery displacement affects bud flush in the initial year of establishment but disappeared within a short time period; (4) seed transfer may be extended up to $5^{\circ}$ northward and $7^{\circ}$ southward with apparent minimal negative implications. However. caution may be needed when transferring provenances from inland regions to the coast. Although this information is useful for initiating seed zone development and seed transfer guideline for paper birch provenances in $\mathrm{BC}$, the result should be considered with caution as findings for this study were based on a small number of provenances. Further study with several common garden experiments at different latitudes and elevations is highly recommended to determine the intra- and inter-population variability and plasticity of this species.

\section{References}

Benowicz A, Guy R, Carlson MR, El-Kassaby YA (2001). Genetic variation among paper birch (Betula papyrifera Marsh.) populations in germination, frost hardiness, gas exchange and growth. Silvae Genetica 50: 7-13. [online] URL: http:// www.silvaegenetica.com/fileadmin/content/doku ment/archiv/silvaegenetica/50_2001/50-1-7.pdf

Bowden-Green R, Rooke H (1980). Projected recovery of plantable trees per bed foot. Unpublished Report, BC Forest Service, Silvicultural Branch, Victoria, BC, Canada, pp. 1.

Campbell RK, Sorensen FC (1984). Genetic implications of nursery practices. In: "Forest Nursery Manual: Production of Bareroot Seedlings" (Duryea ML, Landis TD eds). Martinus Nijhoff/ Dr. W. Junk Publishers, The Hague, The Netherlands, pp. 83-191. - doi: 10.1007/978-94-009-61 10-4_17

Cannell MGR, Smith RI (1986). Climatic warming, spring budburst and frost damage on trees. Journal of Applied Ecology 23: 177-191. - doi: 10.2307/2403090

Carlson MR, Berger VG, Hawkins CDB (2000a). Seed source testing of paper birch (Betula papyrifera) in the interior of British Columbia. Journal of Sustainable Forestry 10: 25-34. - doi: 10.1300/J091v10n01_03

Carlson MR, Hawkins CDB, Berger V, Mahoney R, Hooge BD (2000b). A genecology study of paper birch in British Columbia and Idaho. Unpublished establishment report no. EP106913, BC Ministry of Forests and Range, Victoria, BC, Canada, pp. 1-5.

Chmura DJ, Rozkowski R (2002). Variability of beech provenances in spring and autumn phenology. Silvae Genetica 51 (2/3): 123-127. [online] URL: http://www.rheinischesmuseumfuerphilolo gie.de/fileadmin/content/dokument/archiv/silvaegenetica/51 2002/51-2-3-123.pdf

Dhar A, Hawkins CDB (2013). Differential and interactive effects of photoperiod and tempera- ture on paper birch bud flush. Unpublished data, Mixedwood Ecology project, University of Northern British Columbia, Prince George, BC, Canada. [in preparation]

Dhar A, Balliet N, Hawkins CDB (2014). Variability in height growth, survival and nursery carryover effect of Betula papyrifera provenances. Scandinavian Journal of Forest Research 29: 132-143. - doi: 10.1080/02827581.2014.881541 Fraser DA (1956). Ecological studies of forest trees at Chalk River, Ontario, Canada. II. Ecological conditions and radial increment. Ecology 37: 777-89. - doi: 10.2307/1933069

Gould PJ, Harrington CA, St Claire (2011). Incorporating genetic variation into a model of budburst phenology of coastal Douglas-fir (Pseudotsuga menziesii var. menziesii). Canadian Journal of Forest Research 41: 139-150. - doi: 10.113 9/X10-191

Hamann A, Wang T (2006). Potential effects of climate change on ecosystem and tree species distribution in British Columbia. Ecology 87: 2773-2786. - doi: 10.1890/0012-9658(2006)87 [2773:PEOCCO]2.0.CO;2

Hannerz M (1994). Winter injuries to Norway spruce observed in plantations and in a seed orchard. Report no. 6, SkogForsk, Uppsala, Sweden, pp. 22. [online] URL: http://agris.fao.org/ agris-search/search.do?recordID=SE1995003792 1

Hannerz M, Ekberg I, Norell L (2003). Variation in chilling requirement for completing bud rest among provenances of Norway spruce. Silvae Genetica 52: 161-168.

Hawkins CDB (1998). Interactions of forest seedling nurseries and seed orchards. In: "Tree Improvement: Applied Research and Technology Transfer". (Puri S ed). Science Publishers Inc., Boca Raton, FL, USA, pp. 125-139. [online] URL: http://www.cabdirect.org/abstracts/199906 03448.html

Hawkins CDB, Dhar A (2012). Spring bud phenology of 18 Betula papyrifera populations in British Columbia. Scandinavian Journal of Forest Research 27: 507-519. - doi: 10.1080/02827 581.2012 .671356

Hawkins CDB, Dhar A, Rogers BJ (2012a). How much birch (Betula papyrifera) is too much for maximizing spruce (Picea glauca) growth: a case study in boreal spruce plantation forests, Journal of Forest Science 58 (7): 314-327. [online] URL: http://www.agriculturejournals.cz/publicFiles/69 613.pdf

Hawkins CDB, Dhar A, Lange J (2012b). Vegetation management with glyphosate has little impact on understory species diversity or tree growth in a sub boreal spruce plantation - a case study. Plant Biosystems 147: 105-114. - doi: 10.1080/11263504.2012.736421

Hawkins CDB, Dhar A (2013). Birch (Betula papyrifera) white spruce (Picea glauca) interactions in mixedwood stands: implications for management. Journal of Forest Science 59: 137149. [online] URL: http://www.agriculturejour nals.cz/publicFiles/90899.pdf

Heide OM (1993). Daylength and thermal time re- sponses of budburst during dormancy release in some northern deciduous trees. Physiologia Plantarum 88: 531-540. - doi: 10.1111/j.1399-3054. 1993.tb01368.x

Häkkinen R, Linkosalo T, Hari P (1998). Effects of dormancy and environmental factors on timing of bud burst in Betula pendula. Tree Physiology 18: 707-712. - doi: 10.1093/treephys/18.10. 707

Hänninen H (2006). Climate warming and the risk of frost damage to boreal forest trees: identification of critical ecophysiological traits. Tree Physiology 26: 889-898. - doi: 10.1093/treephys/26. 7.889

Hector A, Felten S, Schmid B (2010). Analysis of variance with unbalanced data: an update for ecology and evolution. Journal of Animal Ecology 79: 308-316. - doi: 10.1111/j.1365-2656.20 09.01634.x

Junttila O, Hänninen H (2012). The minimum temperature for budburst in Betula depends on the state of dormancy. Tree Physiology 32: 337345. - doi: 10.1093/treephys/tps010

Kramer K (1994). Selecting a model to predict the onset of growth of Fagus sylvatica. Journal of Applied Ecology 31: 172-81. - doi: 10.2307/240 4609

Kriebel HB, Wang CW (1962). The interaction between provenance and degree of chilling in bud-break of sugar maple. Silvae Genetica 11: 125-130. [online] URL: http://www.silvaegeneti ca.com/fileadmin/content/dokument/archiv/silva egenetica/11 1962/11-5-6-25.pdf

Lang HP (1989). Risks arising from the reduction of the genetic variability of some Alpine Norway spruce provenances by size grading. Forestry 62 : 49-52.

Langsrud Y (2003). ANOVA for unbalanced data: use Type II instead of Type III sums of squares. Statistics and Computing 13: 163-167. - doi: 10.1023/A:1023260610025

Lewsey JD, Gardiner WP, Gettinby G (1997). A study of simple unbalanced factorial designs that use type II and type III sums of squares. Communications in Statistics - Simulation and Computation 26: 1315-1328. - doi: 10.1080/036109197 08813442

Li C, Junttila O, Ernstsen A, Heino P, Palva ET (2003). Photoperiodic control of growth, cold acclimation and dormancy development in silver birch (Betula pendula) ecotypes. Physiologia Plantarum 117: 206-212. - doi: 10.1034/j.1399-3 054.2003.00002.x

Linkosalo T, Lechowicz MJ (2006). Twilight farred treatment advances leaf bud burst of silver birch (Betula pendula). Tree Physiology 26: 1249-1256. - doi: 10.1093/treephys/26.10.1249

Macnaughton DB (1998). Which sums of squares are best in unbalanced analysis of variance? MatStat Research Consulting Inc., Toronto, Canada, pp. 1-33. [online] URL: http://www.matstat.com/ ss/easleaao.pdf

Morgenstern EK (1996). Geographic variation in forest trees genetic basis and application of knowledge in silviculture. University of British Columbia Press, Vancouver, BC, Canada, pp. 
209. [online] URL: http://agris.fao.org/agrissearch/search.do?recordID=US201300302972

Morison JIL, Morecroft MD (2006). Plant growth and climate change. Blackwell Publishing, Oxford, UK, pp. 232. [online] URL: http://books. google.com/books?id=FzT2GUVUktIC

Murray MB, Cannell MGR, Smith RI (1989). Date of budburst of fifteen tree species in Britain following climatic warming. Journal of Applied Ecology 26: 693-700. - doi: 10.2307/2404093

Myking T, Heide OM (1995). Dormancy release and chilling requirement of buds of latitudinal ecotypes of Betula pendula and B. pubescens. Tree Physiology 15: 697-704. - doi: 10.1093/tree phys/15.11.697

Myking T (1997). Dormancy, budburst and impacts of climatic warming in coastal-inland and altitudinal Betula pendula and B. pubescens ecotypes. In: "Phenology in Seasonal Climates" (Lieth H, Schwartz MD eds). I. Backhuys Publishers, Leiden, The Netherlands, pp. 51-66. [online] URL: http://www.skogoglandskap.no/en/ pubs/SF_1028_906

Myking T, Skroppa T (2007). Variation in phenology and height increment of northern Ulmus glabra populations - implications for conservation. Scandinavian Journal of Forest Research 22: 369-374. - doi: 10.1080/028275807016721 21

O'Driscoll J (1976). Sitka spruce international ten provenance experiment: results to end of Nursery stage. Forest Genetic Resource Information No. 7, Food and Agriculture Organization, Rome, Italy. [online] URL: http://www.fao.org/docrep/ 006/11807e/L1807E06.htm

Park A, Puettmann K, Wilson E, Messier C, Kames S, Dhar A (2014). Can boreal and temperate forest management be adapted to the uncertainties of $21^{\text {st }}$ century climate change? Critical Reviews in Plant Sciences 33 (4): 251-285. - doi: 10.1080/07352689.2014.858956

Pellis A, Laureysens I, Ceulemans R (2004). Genetic variation of bud and leaf phenology of seventeen poplar clones in a short rotation coppice culture. Plant Biology 6: 38-46. - doi: 10.1055/s2003-44746

Pudas E, Leppälä M, Tolvanen A, Poikolainen J, Vanäläinen A, Kubin E (2008). Trends in phenology of Betula pubescens across the boreal zone in Finland. International Journal of Biometeorology 52: 251-259. - doi: 10.1007/s00484007-0126-3

R Core Team (2012). R: a language and environment for statistical computing. R Foundation for Statistical Computing, Vienna, Austria. [online] URL: http://www.R-project.org/

Richards AE, Forrester DI, Bauhus J, SchererLorenzen M (2010). The influence of mixed species tree plantations on the nutrition of individual species: a review. Tree Physiology 30: 1192-1208. - doi: 10.1093/treephys/tpq035

Rousi M, Pusenius J (2005). Variations in phenology and growth of European white birch (Betula pendula) clones. Tree Physiology 25: 201-210. doi: 10.1093/treephys/25.2.201

Sharik TL, Barnes BV (1976). Phenology of shoot growth among diverse populations of yellow birch and sweet birch. Canadian Journal of Botany 54: 2122-2129. - doi: 10.1139/b76-228

Shaw RG, Mitchell-Olds T (1993). ANOVA for unbalanced data: an overview. Ecology 74: 1638-1645. - doi: 10.2307/1939922

Simard SW, Heineman JL, Mather WJ, Sachs DL, Vyse A (2001). Effects of operational brushing on conifers and plant communities in the southern interior of British Columbia: results from PROBE 1991-2000 protocol for operational brushing evaluations. Land Management Handbook No. 48, BC Ministry of Forests, BC, Canada, pp. 379. [online] URL: http://www.for. gov.bc.ca/hfd/pubs/docs/lmh/Lmh48/Lmh48-1. pdf

Simard SW, Sachs DL, Vyse A, Blevins LL (2004). Paper birch competitive effects vary with conifer tree species and stand age in interior British Columbia forests: implications for reforestation policy and practice. Forest Ecology and Management 198: 55-74. - doi: 10.1016/j.foreco. 2004.03.036

Simpson DG, Binder WD, L'Hirondelle S (2000). Paper birch genecology and physiology: spring dormancy release and fall cold acclimation. Journal of Sustainable Forestry 10:191-198. - doi: 10.1300/J091v10n01_22

Sulkinoja M, Valanne T (1987). Leafing and bud size in Betula provenances of different latitudes and altitudes. Report of the Kevo Subarctic Research Station 20: 27-33.
Veen B (1954). General remarks on provenance research in forestry. Euphytica 3: 89-96. - doi: 10.1007/BF00029955

Viherä-Aarnio A, Velling P (2008). Seed transfers of silver birch (Betula pendula) from the Baltic to Finland - Effect on growth and stem quality. Silva Fennica 42: 735-751. - doi: 10.14214/sf.2 26

Vitasse Y, Delzon S, Bresson CC, Michalet R, Kremer A (2009). Altitudinal differentiation in growth and phenology among populations of temperate-zone tree species growing in a common garden. Canadian Journal of Forest Research 39:1259-1269. - doi: 10.1139/X09-054

Wang T, Hamann A Spittlehouse DL, Murdock TQ (2012). ClimateWNA - high-resolution spatial climate data for western North America. Journal of Applied Meteorology and Climatology 51: 16-29. - doi: 10.1175/JAMC-D-11-043.1 Westergaard L, Eriksen EN (1997). Autumn temperature affects the induction of dormancy in first-year seedlings of Acer platanoides L. Scandinavian Journal of Forest Research 12: 11-16. doi: $10.1080 / 02827589709355378$

Wielgolaski FE, Inouye DW (2003). High latitude climates. In: "Tasks for Vegetation Science 39. Phenology: An Integrative Environmental Science" (Schwartz MD ed). Kluwer Academic Publishers, Dordrecht, The Netherlands, pp.175194. - doi: 10.1007/978-94-007-0632-3_12

\section{Supplementary Material}

Tab. SM1 - Coefficient of determination $\left(\mathrm{R}^{2}\right)$ of the linear regressions to $80 \%$ bud flush in 2003 based on origin of different seed sources' environmental variables at three common garden locations.

Tab. SM2 - Principal component analysis (PCA) of four climate normal variables at province collection locations.

Fig. SM1 - Principal component analysis (PCA) of provenance source location climate variables.

Link: Dhar_1367@supp1001.pdf 